\title{
Cultivation of the Innovative Ability Students in Mechanical Engineering with Subject Competition and outcome-based Education
}

\author{
Quansheng Jiang ${ }^{1, a^{*}}$, Ziyang Cao ${ }^{1, b}$ and Bangfu Wang ${ }^{1, c}$ \\ ${ }^{1}$ School of Mechanical Engineering, Suzhou University of Science and \\ Technology, Suzhou 215009, China \\ ajqs1996@163.com, bycao@163.com, csunboy02@126.com \\ *The Corresponding author
}

Keywords: Subject competition; Outcomes-based education; Innovation ability; Talent training

\begin{abstract}
The subject competition of college students is an important carrier for the cultivation of innovative talent. It has a unique effect on cultivating students' innovation ability, improving teaching quality and promoting teaching reform in universities. In this paper, On the basis of comprehensively summarizing mechanical discipline competition experience in Suzhou University of Science and Technology, and combined with the Outcomes-based education, the training mode of mechanical majors discipline competition mechanism and innovation ability is explored, and the effective way to cultivate the innovative talents of college students is pointed out.
\end{abstract}

\section{Introduction}

In the knowledge economy, high-quality innovative talents become a common demand of society, and innovation training has become an important mission of higher education [1-2]. The undergraduate education teaching key requirements of Suzhou University of Science and Technology focus on cultivating students' innovative consciousness and practical ability. The subject competition is an important carrier of cultivating innovative talents. It has a unique role in improving the overall quality of college students, cultivating students' innovation ability, improving teaching quality and promoting the reform of education and teaching in universities [3].

School of Mechanical Engineering in Suzhou University of Science and Technology has always adhered to the cultivation of high-quality composite talents as a fundamental task, to build a personnel training system of "high-quality, strong application, re-innovation". Around the application of knowledge, practice and innovation of students, we formed a college student innovation training base as a platform for the competition mechanism. On the basis of scientific training projects and outcomes-based education mode, we aim at the cultivate students' practical innovation ability and develop their comprehensive quality.

\section{Subject Competition is an Important Way to Improve the Innovation Practice Ability of College Students}

Subject competition has become an important carrier to enhance the practical ability of college students [4]. The content of the subject competition usually has a certain application background or project background, which is extensive and comprehensive, often involving multiple disciplines knowledge [5]. In the national undergraduate mechanical innovation design competition and other competitions, we actively encourage and guide students to interdisciplinary, grade and professional team, to promote the application of knowledge integration; at the same time, to encourage more students to participate for the purpose of exercising and improving practice ability in a wide application background of facing practical problems and application potential. For the students, the process of competition is the ability to analyze and solve problems independently, and to improve the professional quality of students, cultivating the ability of information acquisition, organization and management ability, the ability of communication and expression. 
A high level of subject competition, can not only cultivate students' comprehensive use of basic knowledge and willpower, but also can cultivate students' innovation consciousness and team spirit. The subject competition can improve the students' practical ability and innovation ability, and will promote the school education practice work thorough development, finally to improve the comprehensive quality of college students.

\section{Outcomes-based Education Mode for Improving the Undergraduate Innovation Practice Ability}

Outcomes-based education is based on the expected learning output as the center to organize, implement and evaluate the structural model of education. It defines the implementation of all the educational activities, instructional design, curriculum and teaching implementation are carried out around the students to achieve the desired learning outcomes. There are four main steps to implementing the OBE education model: Defining, Realizing, Assessing, and Using. The comparison of learning systems between Outcomes-based education and Content-based education is seen in Table 1.

Table 1 Comparison of learning systems between Outcomes-based education and Content-based education

\begin{tabular}{|c|l|l|}
\hline $\begin{array}{c}\text { Learning system } \\
\text { features }\end{array}$ & \multicolumn{1}{|c|}{ Content-based education } & \multicolumn{1}{c|}{ Outcomes-based education } \\
\hline Frame & $\begin{array}{l}\text { Preset curriculum assessment and } \\
\text { certification program, the structure is } \\
\text { the purpose, and the learner outcomes } \\
\text { are not defined. }\end{array}$ & $\begin{array}{l}\text { Open courses, teaching strategies, } \\
\text { evaluation and behavior standards; the } \\
\text { realization of the goal from teaching } \\
\text { structure. }\end{array}$ \\
\hline Time & $\begin{array}{l}\text { Rigid constraints, teaching schedules } \\
\text { control learning and success. }\end{array}$ & $\begin{array}{l}\text { Use of resources that can be changed } \\
\text { according to the needs of educators and } \\
\text { learners. }\end{array}$ \\
\hline Standard & $\begin{array}{l}\text { Method of comparison and } \\
\text { competition, the normal distribution } \\
\text { curve is set up beforehand. }\end{array}$ & $\begin{array}{l}\text { The learner can obtain the credits when } \\
\text { achieve the standard, not by the } \\
\text { proportion or standard limit. }\end{array}$ \\
\hline Study Evaluation & $\begin{array}{l}\text { Continuous exams and fractional } \\
\text { errors are permanently recorded; slow } \\
\text { learners are unable to keep up with the } \\
\text { pace of learning. }\end{array}$ & $\begin{array}{l}\text { Take a macroscopic view of learning } \\
\text { achievement and make clear what the } \\
\text { ultimate achievement is. }\end{array}$ \\
\hline
\end{tabular}

In essence, the OBE model revolves around the main line of "defining the expected outcomes achieving the expected outcomes - assessing the outcomes", and the student outcomes assessment constitutes a closed loop of continuous improvement in the quality of education. Therefore, the core concepts of OBE are "student center", "result orientation" and "continuous improvement". Fig. 1 is the curriculum design model based on OBE. 


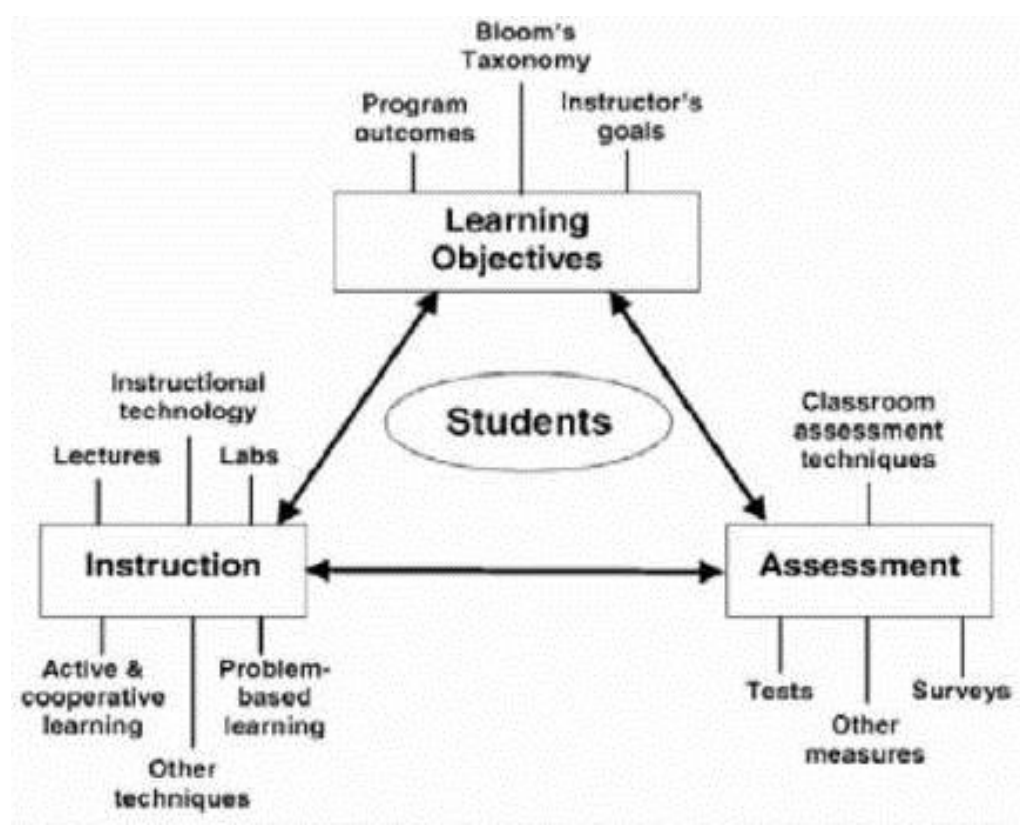

Figure 1. Finite The curriculum design model based on OBE

In the OBE model, students can clearly feel the expectations from the teacher, gain experience through continuous formative assessment. At the same time, as long as the expected learning output can be achieved, students can learn from different educational institutions experience, and participate in different types of educational activities.

\section{Our Measures on Subject Competition and Outcomes-Based Education}

To cultivation of innovative ability of students in mechanical engineering, we construct the training system of discipline competition through the main links of talent cultivation and outcomes-based education.

Among our measures, strengthen the construction of innovation education platform, actively create conditions to support and encourage students to participate in the competition of all kinds of college students with the help of innovation platform. The discipline competition we organized currently pays more attention to the integration of knowledge, interdisciplinary, ability and teamwork spirit, and is developed from the single discipline to the direction of comprehensive, multidisciplinary, interdisciplinary, innovative, and operational effectiveness.

Discipline competition should be combined with knowledge, quality, ability and school education reform. The content of the competition should be continuous innovation, so as to expand to the "depth", organize diversified competition, focusing on improving students' practical innovation ability; to promote the "breadth", pay attention to the coverage, advocate and encourage students to participate in more than two different academic competition project. On the other hand, to advocate the combination of competition and scientific research training, expand students' participation, highlight the "display", and expand the influence.

The discipline competition is turning to the three combined aspects that "teaching and learning, in class and after class, process evaluation or result evaluation". We also give these measures that cultivating student' autonomy, initiative and inquiry learning; to promote the entry into the first class; to strengthen the participation process and to reduce the utility.

Actively explore the form of organization and discipline competition based on the problems and field, put forth effort to improve students' innovative spirit and ability to solve the problem of the practice ability, which transform the outstanding achievements and works, expand social and employment needs.

Actively promote the integration of discipline competition and academic exchanges, scientific research training, graduation thesis (design). Based on the innovation training base of college students, 
the combination of discipline competition and innovation activities, a multi-level innovation education system and a guarantee mechanism to support students' independent management and independent innovation has been established.

Actively study the discipline competition on the cultivation of innovation ability and the construction of experimental teaching platform, experimental courses and project construction, etc. To explore the long term mechanism of discipline competition.

Aiming at the deficiency of the discipline competition, we strengthen the connotation construction of discipline competition by using mode of Outcomes-based education.

\section{Work Effectiveness on Cultivation the Innovative Ability of Students}

Taking the discipline competition as the turning point, we cultivate students' comprehensive ability through the platform such as the National College mechanical innovation design competition, China Engineering Robot Contest \& International Open, National college students' innovation and entrepreneurship training programs, and other important extracurricular activities of science and technology contest.

In 2016, our students have gained the first prize at the seventh session of the National College of mechanical innovation design contest. In the seventh session of the National College of mechanical innovation design contest in Jiangsu province zone, we obtained a total of four pieces of our school award-winning work, including the first prize is one item, the two prize is two, the third-prize is one.

In 2016 China Engineering Robot Contest \& International Open, our students have gained the first prize with two items, the second prize is three items, and the third-prize is four items. Moreover, our students have received a total of 8 patents.

\section{Summary}

The fundamental purpose of higher education is to train a large number of high-quality talents with innovative ability. The measures of carrying out extracurricular activities of science and technology, strengthen practice, is an important supplement and extension of classroom teaching, which stimulate students' innovation consciousness. We carry out the discipline competition, combined with using mode of Outcomes-based education, and guide students to think actively, learn in practice as well as in the study practice, combining theory with practice, improve the students' thirst for knowledge and exploration. The measures cultivate engineering consciousness and innovation ability of students, improve the ability of analyzing and solving problems.

\section{Acknowledgements}

This research is supported by the teaching reform and research project of Suzhou University of Science and Technology in 2015 (2015JGM-20).

\section{References}

[1] Xihong Wang, Liangcheng Wang, Mi Zhou, Discussion on the enhancement of science and engineering students' practical and innovative ability through academic contests, Laboratory Science. 9(2011) 1-3. (In Chinese)

[2] Min Wan, Constructing College Student Ability Training Mode Based on Academic Competitions, Journal of Xichang College (Natural Science Edition). 25(2011) 145-147. (In Chinese)

[3] Chun Xiao, Explorations and Studies on Academic Competition System Based on Outstanding Engineer Cultivation, Journal of Zhejiang University of Technology(Social Science). 10 (2011) 205-209. (In Chinese) 
[4] Wanfu Dong, Zhipin Nie, The Practice and Research on the Ability Build of Creative Design for Student in Mechanics. Journal of Chengdu University (Educational Sciences Edition). 21(2007) 32-33. (In Chinese)

[5] Baoxian Hong, Bingbing Gong, Siwei Bao, Status and Thinking of Academic Competition at Local University, Journal of Taizhou University. 33(2011) 70-73. (In Chinese) 